\title{
PERMINERALIZED INFRUCTESCENCE FROM THE CERRO DEL PUEBLO FORMATION, UPPER CRETACEOUS, COAHUILA, MEXICO.
}

\begin{tabular}{|r|l|}
\hline Journal: & Botany \\
\hline Manuscript ID & cjb-2016-0058.R3 \\
\hline Manuscript Type: & Article \\
\hline Date Submitted by the Author: & 14 -Jul-2016 \\
\hline Complete List of Authors: & $\begin{array}{l}\text { Cevallos-Ferriz, Sergio; Universidad Nacional Autonoma de Mexico, } \\
\text { Instituto de Geología } \\
\text { Vázquez-Rueda, Mar-Allesha; Universidad Nacional Autonoma de Mexico, } \\
\text { Facultad de Ciencias }\end{array}$ \\
\hline Keyword: & $\begin{array}{l}\text { Campanian/Maastrichtian, Coahuila, Infructescence, Cerro del Pueblo } \\
\text { Formation, fruit anatomy }\end{array}$ \\
\hline &
\end{tabular}


PERMINERALIZED INFRUCTESCENCE FROM THE CERRO DEL PUEBLO FORMATION, UPPER CRETACEOUS, COAHUILA, MEXICO.

Cevallos-Ferriz Sergio $\mathrm{R} \mathrm{S}^{1}$ and Vázquez-Rueda Mar-Allesha ${ }^{2}$

${ }^{1}$ Instituto de Geología, UNAM; Ciudad Universitaria, Circuito de la Investigación Científica, Copilco El Alto, Coyoacan; 04510 México D.F., México. scrscfpb@unam.mx

${ }^{2}$ Facultad de Ciencias, UNAM; Ciudad Universitaria, Circuito de la Investigación Científica, Copilco El Alto, Coyoacan; 04510 México D.F., México. mar-allesha@hotmail.com

\footnotetext{
${ }^{1}$ Corresponding author: Sergio RS Cevallos-Ferriz; Instituto de Geología, UNAM; Ciudad Universitaria, Circuito de la Investigación Científica, Copilco El Alto, Coyoacan; 04510 México D.F., México; tel. 5255 56224312 ext.196; fax 5255 56224281; scrscfpb@unam.mx
} 


\section{Summary}

Permineralized infructescences are described from the Cerro del Pueblo Formation, Coahuila, Mexico. Morphological and anatomical observations of 584 infructescences support the identification and reconstruction of an infructescence, with fruits developed as nutlets. Fruits are each surrounded by bracts, and have a persistent style and stigma. They are comprised of a woody exocarp composed of macrosclereids, and mesocarp and endocarp with layers of brachysclereids. Seeds are fusiform with a thin seed coat. Seeds contain a distal hollow chamber probably involved in dispersal, an embryo with two cotyledons with probable helobial endosperm. The fruit and seed characters of the fossil do not correspond with an extant genus, or a family, thus, a new genus and species is proposed, Patocarpus coahuilensis Cevallos-Ferriz and Vázquez -Rueda, and is interpreted as an extinct member of Proteales.

Key words: Infructescence, Campanian/Maastrichtian, Cerro del Pueblo Formation, Coahuila, fruit anatomy 


\section{Introduction}

Fossil flowering plants from Cretaceous strata in Mexico were first studied from the Olmos Formation of Coahuila (Vaughan 1900; Boese and Cavins 1927). Later, in 1972 Reinhard Weber made one of the most complete collections of these impression/compressions floras and provided a preliminary description of ferns, conifers and angiosperms (Weber 1972). More recently, a variety of palms roots and stems were described (Cevallos-Ferriz and Ricalde-Moreno 1995), and Estrada-Ruiz and collaborators (2007, 2008, 2009, 2011) added important information on the diversity and climate of this geologic unit.

In recent years several angiosperm macrofossils have been reported from Cretaceous sediments of Mexico (Estrada-Ruiz and collaborators 2007, 2008, 2009, 2011). In sediments ca. 96 mya old in the state of Chiapas, seven different angiosperm plants were collected (Cevallos-Ferriz and Huerta-Vergara 2015), and a leaf assemblage from the state of Sonora, which resemble that of the Potomac Group level II has been reported also Cretaceous deposits in the state of Sonora near the town of Huepac, an extinct aquatic plant with an affinity to Haloragaceae is the most complete known fossil plant from Mexico (Hernandez-Castillo and Cevallos-Ferriz 1999; Table 1).

The study of plants from the Cretaceous Cerro del Pueblo Formation, which is the focus of this paper, began in 1984 when Silva-Pineda described two types of fruits collected near the San Antonio Dam, City of Parras. They were subsequently reviewed by Rodriguez-de la Rosa and Cevallos-Ferriz (1994), suggesting similarity to Musaceae and Strelitziaceae, and are now reassigned to Strelitziaceae. Calvillo-Canadell (2000) documented the presence of Rhamnaceae describing the ripening of a flower to a fruit (Table 1). Estrada-Ruiz (2004), 
Estrada and Cevallos-Ferriz (2007) and Cevallos-Ferriz et al. (2008) described fruits of Arales and Phytolaccaceae, and Rodriguez-de la Rosa et al. (1998) discussed plant-animal interactions based on plant remains inside coprolites, in which seeds of Lythraceae and Ranunculaceae were documented. More recently, Estrada-Ruiz et al. (2009) reported isolated fruits of Ceratophyllum. These studies are good examples of the taxonomic challenge these permineralized reproductive organs represent. One fruit type was identified as an extinct species of an extant genus, whereas others were classified as representing extinct genera within a modern family, but some are difficult to assign to a single order.

The most commonly studied fossils other than plants from the Cerro del Pueblo Formation are invertebrates and vertebrates (e.g., Boyd 1959; McBride et al. 1974; Hernández 1992; Hernández and Kirkland 1993; Hernández et al. 1995; Woolleben 1997; Kirkland et al. 2000, 2006; Rodriguez de la Rosa and Cevallos-Ferriz 1998; Kirkland and Aguillón-Martínez 2002; Cifuentes-Ruiz et al. 2006; Prieto-Márquez and Serrano-Braña 2012).

Here we describe a newly recognized infructescence from the Cerro del Pueblo Formation. Comparisons with extant taxa strongly suggest the presence of an extinct plant with no clear taxonomic affinity (Table 2). Patocarpus coahuilensis gen. et. sp. nov. Cevallos-Ferriz and Vázquez -Rueda, is proposed in order to recognize its unique mosaic of morphological and anatomical characters.

\section{Materials and methods}


The fossil material was collected during several field trips between 1993 and 1999 in the Ejidos of Rincón Colorado and Presa San Antonio, Coahuila, by members of the Paleobotany Laboratory of the Instituto de Geología, UNAM, and of the Superior Normal School of the state of Coahuila. The material was cataloged and deposited as part of the Paleontological Collection of the Instituto de Geología, UNAM.

Coahuila is located in central Northern Mexico (Fig. 1). It has a complex geological history; it belongs to the Oaxaquia Block, and is contiguous with layers of the Ouachita Belt suture, in South Texas (Dickinson and Lawton 2001). This geological region is interpreted as a segment of Gondwana (Dickinson and Lawton 2001), which was united to Laurencia during the Ouachita Orogeny in the Early Permian (Coney 1983).

The Cerro del Pueblo Formation is located north of Saltillo, where several fossil localities are known. Two of the most recognized are Rincón Colorado and Presa San Antonio, in the municipality of General Zepeda, Coahuila, where the fossil material was collected (Eberth et al. 2004). Its age is estimated as late Campanian-Maastrichtian (McBride et al. 1974), or late Campanian (Kirkland et al. 2000). It belongs to the Difunta group in the Parras Basin (which extends to Nuevo Leon), has a thickness of 4,000 m (McBride et al. 1974), and is characterized by a variety of alternate terrestrial and marine sediments. It has been interpreted as a low-lying area covered by sea and coastal lagoons, stretching from northern Saltillo to Monterrey (McBride et al. 1974;. Kirkland et al. 2000). Geological studies in the region indicate that the environment was characterized by frequent flood events generated by storms (McBride et al. 1974; Kirkland et al. 2000; Eberth et al. 2004); the weather was hot and humid, with abundant rainfall, allowing for the existence of a 
tropical/subtropical rainforests. Moreover, almost the entire year, the water level of the swamps and marshes did not vary annually (Eberth et al. 2004).

Five hundred and eighty four (584) permineralized infructescences were collected and analyzed for this study. Of this group 80 of the best preserved were selected for further examination by preparing 255 thin-sections for anatomical observations. Based on these materials cell sizes were measured and the detailed description of the tissues were made. Each infructescence was sectioned with a Buehler rotary disc with a diamond blade. For the description of the morphology and anatomy of infructescence transverse and longitudinal thin sections were oriented in relation to their longitudinal axis. Thin sections of the individual fruits were oriented radially and tangentially with reference to their longitudinal axis. Their length, width, height or diameter is indicated in $\mu \mathrm{m}$ and $\mathrm{mm}$, based on 25 measurements per character.

The morphological and anatomical observations of the fossil material were made using an Olympus SZH stereomicroscope, a Zeiss Stemi DV 4 with a KL 1500 LCD lamp, a Zeiss Primo Star, and a Zeiss petrographic microscope A1 AX10. Photographs were taken with a Canon EOS $1000 D$ camera. Based on the observations, Some fruits were observed under SEM using a Jeol, JSM-5310LV microscope in the Faculty of Sciences, UNAM.

\section{Systematic description}

Division: Magnoliophyta

Class: Eudicots

Order: Proteales 
Family: Incertae sedis

Genus: Patocarpus gen. nov. Cevallos-Ferriz and Vázquez-Rueda

Species: Patocarpus coahuilensis Cevallos-Ferriz and Vázquez

-Rueda

Type locality: Presa San Antonio, Municipio de Parras, Cerro del Pueblo Formation, Coahuila, Mexico.

Age: Late Cretaceous (late Campanian-Maastrichtian), Cerro del Pueblo Formation.

Holotype: GLpb 10632, Paleobotanical Collection of the Paleontological Museum of the Institute of Geology, National Autonomous University of Mexico.

Material studied: 584 permineralized infructescences, Nos. IGLpb 10267-10851; 255 thinsections were prepared from specimens Nos. IGLpb 10367-10388, 10611-10615, 10810$10812,10820-10822$.

Generic diagnosis: Woody spike, fruits arranged spirally, enclosed by two laminar bracts; gynoecium syncarpous; fruits dry, indehiscent, each with persistent style and stigma, three-layered, with exocarp, mesocarp and endocarp; one fusiform seed per carpel, axile placentation; bilayered seed coat; endosperm helobial; hollow chamber in distal zone of the seed, embryo straight, with two cotyledons, lateral position.

Specific diagnosis: Woody spike with 120-150 fruits; fruit bracts three cell layered, abaxial and adaxial epidermis composed of crushed or undifferentiated cells, mesophyll of hexagonal parenchyma cells with intercellular spaces in the distal zone, and circular cells in the proximal zone; gynoecia composed of one to four carpels; placentation axile, syncarpous fruits. Fruits dry and indehiscent, with a single persistent style and stigma; 
pedicels with several vascular bundles; exocarp composed of a single layer of macrosclereids, mesocarp consisting of a layer of brachysclereids, endocarp of 2 - 3 brachysclereid layers; mesophyll/cortex of pedicel and style composed of brachysclereids; stigma capitate; each carpel bears a single fusiform seed, seed coat with rectangular thinwalled inner cells and an undifferentiated (crushed) outside layer; hilum poorly marked, funicle composed of rectangular to isodiametric cells; cellular endosperm in seed periphery, nuclear endosperm located towards central part of the seed, and grouped near the placenta zone; hollow chamber in distal zone bounded by endosperm, epicotyl and hypocotyl zones well differentiated, two cotyledons with isodiametric epidermal cells, placental vasculature reaching seeds, apical meristem cells.

Description: Woody spike, 160 - 320 mm long and 150 - 180 mm in diameter (Fig. 2A-G). The fruits develop from superior ovaries with a short pedicel, $10 \mathrm{~mm}$ long and $3 \mathrm{~mm}$ in diameter (Fig. 3C), and are spirally arranged along the infructescence axis, from which vascular bundles 125 - $200 \mu \mathrm{m}$ in diameter enter each fruit (Fig. 3D). Each infructescence bears 120 - 150 individual fruits (Fig. 2B and 4C).

Each fruit is $50 \mathrm{~mm}$ long and 20 to $30 \mathrm{~mm}$ in diameter. They are dry and indehiscent, unicarpellate, or syncarpous with bi, tri or tetracarpelar (Fig. 2D). The fruits have a single apical, solid style (Fig. 3A) and a stigma, $275 \mathrm{~mm}$ in diameter (Fig. 3B).

Two thin laminar bracts, $50 \mathrm{~mm}$ long and $10 \mathrm{~mm}$ wide enclose each fruit. The mesophyll of each bract is composed of aerenchyma with intercellular spaces ca. $80 \mu \mathrm{m}$ in diameter and hexagonal parenchymal cells towards the distal zone (Fig. 3E, F), and of 2-3 cell layers of 
isodiametric cells, $70 \mu \mathrm{m}$ in diameter, toward the proximal zone (Fig. 3D, E). The epidermis is composed of a layer of crushed, or undifferentiated, cells.

The fruits themselves are composed of three distinct cell layers (Fig. 4A). The exocarp is woody and composed of a single layer of macrosclereids, $55 \mu \mathrm{m}$ long, $25 \mu \mathrm{m}$ wide, and ca. $15 \mu \mathrm{m}$ high (Fig. 4B). The mesocarp and endocarp are composed of thick-walled, rectangular or isodiametric, pitted brachysclereids, that are $15-25 \mu \mathrm{m}$ wide, $15-20 \mu \mathrm{m}$ long and $10 \mu \mathrm{m}$ high (Fig. 4D). These cells extend toward the style (Fig. 4E) covering the septum and the area of the placenta where cells increase in size to $60 \mu \mathrm{m}$ long, $50 \mu \mathrm{m}$ wide and $10 \mu \mathrm{m}$ high (Fig. 4F). Similar brachysclereids make up the cortex of the fruit pedicel (Fig. 4G).

A single fusiform seed is present per carpel. Their size varies between $2-3 \mathrm{~mm}$ in length and 7 - $10 \mathrm{~mm}$ in diameter, to $5.3 \mathrm{~mm}$ in diameter near the proximal and distal ends (Fig. 5A). Seeds are free from the carpel except at the placental region where they developed from epitropous ovules (Fig. 5B). The funiculus is composed of rectangular or isodiametric cells, $60 \mu \mathrm{m} \times, 50 \mu \mathrm{m} \times 10 \mu \mathrm{m}$. The hilum is poorly marked. The seed coat is composed of a crushed, or undifferentiated, outer layer and an inner one of rectangular cells, $10 \mu \mathrm{m} \times 5$ $\mu \mathrm{m} \times 6 \mu \mathrm{m}$; however, they become smaller towards the seed poles (Fig. 5C). Seed endosperm has helobial development (Fig. 5D). Cells of the cellular endosperm are $25 \mu \mathrm{m}$ in diameter and located toward the periphery of the seed (Fig. 5E, F). Nuclei of the nuclear endosperm are $15 \mu \mathrm{m}$ in diameter and are located toward the central portion of the seed and near the placenta (Fig. 5F). Each seed has a hollow chamber located towards the 
chalazal zone that is surrounded by endosperm. Nuclear endosperm bounds the chamber while cellular endosperm develops toward the seed coat (Fig. 5G).

The best-preserved embryo is $1.26 \mathrm{~mm}$ long, and occupies a median position in the seed cavity (Fig. $5 \mathrm{H}$ ). In the distal part of the embryo the epicotyl differentiates, reaching 500 $\mu \mathrm{m}$ in diameter (Fig. $5 \mathrm{H}$ ). In the proximal part of the embryo the hypocotyl has a smaller diameter, up to $225 \mu \mathrm{m}$ (Fig. 5H). Two cotyledons flank the apical meristem composed of isodiametric cells, $12 \mu \mathrm{m}$ in diameter (Fig. 5H). Smaller isodiametric cells delimit the cotyledons, 16 to $18 \mu \mathrm{m}$ in diameter (Fig. $5 \mathrm{H}$ ).

\section{Discussion}

The reproductive structures studied here are interpreted as an axis carrying only female flowers, because no male flowers were observed, and no evidence of scars of floral remains suggesting the presence of an androecium (filaments or stamens) was observed. The fossil infructescence is woody bearing indehiscent fruits, that could be named as angiocarps (fruit wrapped or protected by an outer structure; Moreno 1984; Figs. 6 - 9).

Fruit morphology along the infructescence varies in the number of carpels. For example, a nut describes a simple, dry, indehiscent fruit with one seed and hardenwed pericarp, generally derived from a unilocular ovary (Moreno 1984), as shown in the less common unicarpellate fruits. Nutlet refers to indehiscent dry fruits, developed from a syncarpous, plurilocular superior ovary (Moreno 1984), as exemplified by the bi- tri- and tetracarpellate fruits in the fossil material (Figs. 6 -9). Since the variability in the number of carpels and seeds per fruit may be caused by the presence of abortive carpels and 
seeds the new plant is described as having nutlets. This is a well-known phenomenon, and indeed occurs in Pontederiaceae (Graham and Barrett 1995).

The presence of a single embryo in a fruit located toward the middle part of an infructescence (Fig. 5H), suggests that each one of the flowers composing the inflorescence were at anthesis and was pollinated at different times (e.g., Fuentes 1994; Prasanna et al. 2007). The fruits towards the proximal and distal zones of the infructescence are less developed than those of the central part. Thus, it is suggested that ripening of the reproductive structures proceeded from the center of the infructescence toward its poles.

Infructescence, fruit, and seed reconstructions make the new reproductive organ different from extant plant groups. Little similarity was found with reproductive organs of know extant and fossil plants. The presence of valves or bracts, chalazal chamber and endosperm type are unique to the new reproductive structure. These characters have not been found in any single extant or fossil plant group, though some similarities with members of Altingiaceae, Fagaceae, Platanaceae and Proteaceae (e.g., Yarmolenko 1935; McNamara and Scott 1983; Manchester 1986; Friis et al. 1988; Watson and Dallwitz 1992; Crane et al. 1993; Endrees 1993; Pedersen et al. 1994; Mai 1995; Magallón-Puebla 1997; Sims et al. 1998; Borgardt and Pigg 1999; Zhou et al. 2001; Maslova and Kodrul 2003; Pigg et al. 2004; Maslova and Herman 2006; Takahashi et al. 2008; Lohmueller 2009; Maslova 2009; Dallwitz 2010; Friis et al. 2011; Tekleva 2012) can be discussed; however, little support was found to suggest any taxonomic relationship with them (Table 2).

Some extant Altingiaceae share morphological characters with the fossils, like the 
persistent style and stigma, and number of fused carpels that form the individual fruits, but the endosperm type, embryo form, and the number of seeds, do not support any particular relationship (e.g., Endrees 1993; Mai 1995; Pigg et al. 2004; Maslova 2009; Table 2). Extant Fagaceae and the new fossil share the form of the nuts, the presence of syncarpous gynoecia, and the development of one seed per fruit. Nevertheless, the development of 1-2 seeds per locule, and the absence of endosperm in this family ruled out any close taxonomic relationship (Table 2).

Similar to our fossil, Platanaceae fruits have persistent style and stigma. They may develop one or two seeds per fruit, and as the seeds mature, different types of endosperm, even helobial, may be present. This variability depends on the species. Interpretation of this character may be difficult since a vacuole in the distal region of the seed of Platanus racemosa has some resemblance to the chamber in the distal zone of the seed of the new plant (e.g., Yarmolenko 1935; Crane et al. 1993; Pedersen et al. 1994; Friis et al. 1988; Maslova and Herman 2006; Tekleva 2012; Table 2). However, the overall shape of the infructescences and fruits, the number of seeds per locule, and the presence of a vacuole rather than a chamber certainly limits any relationship between Platanaceae and the new Cretaceous reproductive organ.

In contrast, comparison of the new fossil reproductive structures to those of Proteaceae taxa suggests more similarities. They include the type of infructescence and fruit, the presence of persistent bracts in the fruit, the number of carpels, style, stigma, and locules per gynoecium, and the presence of a valve structure (e.g., McNamara and Scott 1983; Friis et al. 2011). The fossil material strongly suggest that the nutlets are covered by 
laminar bracts (Figs. 6 - 9) that can be compared with the valves associated with the fruits of some extant plants in Proteaceae. Furthermore, in both in the fossil and Proteaceae these structures are woody, composed of sclereids. However, valves are not restricted to this family. For example, in Nelumbonaceae (Proteales) fruit dehiscence is described as occurring along two valves. Similar accessory structures referred as bract or bracteoles are described in the fruit of Platanaceae. The three families are grouped in Proteales, an order in which the presence of helobial endosperm has been thoroughly documented (e.g., Taylor and Hopper 1988; Floyd et al. 1999). Documentation of endosperm, perisperm, and helobial endosperm in the fossil material is complicated since details of seed development were not preserved in the fossil material are needed. Nevertheless, as described above, in the seed cavity of the new plant where endosperm would be expected to be present two distinct tissues are preserved. These can be described as cellular and/or cenobial. Dark structures that tend to be polyhedral to circular are frequently grouped in different parts of the seed cavity, but in other areas these dark structures are bounded by thin walls. These structures could be a preservation artifact, these structures (tissues or cenobia) are present only in the seed cavity, and their position and "developmental" stage varies with the size of the seed or fruit. We suggest that the amount of the nuclear or cellular phase of these tissues varied with age. This morphological and anatomical observation suggests the presence of a helobial-like endosperm in the fossil plant; however, evidence is insufficient to confirm its presence. Confirmation of the presence of helobial endosperm would require documenting developmental features at the cellular ultra structural level that certainly were not be preserved in these limonitized fossils. 
A third important character of the fossil reproductive structures is the presence of a hollow chamber located toward the distal zone of the seed. This is an uncommon character among flowering plants, but well known for example in Musaceae and Ranunculaceae (e.g., Rodríguez de la Rosa et al. 1998; Rodríguez de la Rosa and CevallosFerriz 2004; Pigg and deVore 2005). However, the morphology and anatomy of the fruit and seed of the new fossil is completely different from that of the banana and buttercup families and closely related taxa. Interestingly, in members of Proteales, and especially in some Proteaceae and Platanaceae, a vacuole develops in approximately the same area where the chamber is located in the fossil material. Although this is an important character that may help define taxonomic relationships, it is necessary to have finer and more complete observation on the nature and developmental process of the chamber of the fossil material to compare it to similar structures among extant plants.

Since the idea of a helobial-like endosperm is present in the reconstruction of the new fossil infructescence, a relationship to a monocotyledonous group must be discussed. Furthermore, scattered vascular bundles in the cortex of the pedicel further suggest the presence of a monocotyledonous plant. However, this character may be due to a profuse vascularization of the fruit from the pedicel, and more detailed observations are needed to further document this condition. An embryo was found among the studied material, and its preservation is fine enough as to recognize the presence of two cotyledons, a character that would weaken a relationship to the Helobiales (Monocotyledons; Swamy and Parameswaran 2008). The development of the helobial endosperm is preceded by the formation of two chambers in the embryo sac. The first division of the primary endosperm 
nucleus is followed by the deposition of a transverse wall. This wall divides the embryo sac into a small chalazal chamber and a large micropylar chamber. Then the nuclei in each chamber divide by free nuclear divisions. Few nuclear divisions occur in the chalazal chamber and the endosperm in this chamber degenerates. Walls develop between nuclei in the micropylar chamber and thus, produce cellular endosperm (Swamy and Parameswaran 2008). At this moment it is not possible to confirm a similar development in the fossil material, but it is of interest for further studies that a chalazal chamber may be present in monocots and that the chamber in the fossil material, could be related to this developmental process.

Similarity in shape between infructescence and fruits, persistence of bracts, variation in carpel number and locules, development of two types of endosperm, presence of a chamber and a valve, both involved in seed dispersal, are important characters that support a taxonomic relationship between the fossil material and Proteales. Furthermore, the floral structure of Proteaceae and that of the fossil material are also similar. They both share the infructescence organized as a spike, unisexual flowers, absence of calyx and corolla, superior ovary, and one to two ovules per fruit with axile placentation (Fig. 10). The morphological and anatomical organization of the new reproductive structure is present in Proteales; however, the specific organization described for the fossil plant does not exist in any extant member of the order.

The presence of members of Proteales in the Cerro del Pueblo Formation along with a member of Nelumbonaceae (Proteales) in the Olmos Formation (Weber 1972, 1978; Estrada Ruiz et al. 2008) not only expands knowledge on the Proteales diversity and 
distribution, but also suggests that members of the order were successful in colonizing extensive areas of Coahuila during the Late Cretaceous. Pollen grains of Proteales are common element in the Cretaceous sediments of northern Mexico (Villanueva-Amadoz et al. 2014). No Platanaceae have yet been reported from the Cerro del Pueblo and Olmos Formations, but their modern, cosmopolitan distribution suggests that it should be found in the Cretaceous flora of Northern Mexico. This new plant, reported here, adds information to the discussion of the plant exchange patterns between Gondwana and Laurasia (Weishampel 1990; Rodriguez-de la Rosa and Cevallos-Ferriz 1994, 1998. Brinkman et al. 2002, Gates et al. 2005). A detailed examination of this biogeographic process is beyond this report, but certainly represents a challenge that needs of clarification to further understand the distribution pattern of this and other related plant groups.

\section{Acknowledgements}

Authors recognize the opportunity to contribute to this special volume in honor of $\mathrm{Dr}$. Ruth A. Stockey, great teacher, researcher with singular intuition, and overall a special friend. Comments by Dr. Steven R. Manchester, Dr. Jiří Kvaček and an anonymous reviewer are appreciated; they greatly enhanced this manuscript. Aldo Domínguez de la Torre made the illustrations of the fossil fruits and infructescence. Conversations with Drs. Hilda Flores Olvera, Judith Márquez Guzmán and Citlalli Núñez Mariel were important to interpret, compare and discuss, morphological and anatomical details of extant and fossil 
plants. This contribution was partially funded by Conacyt (México) 221129 and PAPIITUNAM IN210416 research projects to SRSCF. 


\section{References}

Boese, E., and Cavins, O.A. 1927. The Cretaceous and Tertiary of Southern Texas and Northern Mexico. Tex. Uni. Bull. 2748:7-142.

Borgardt, S.J., and Pigg, K. 1999. Anatomical and developmental study of petrified Quercus (Fagaceae) fruits from the middle Miocene, Yakima Canyon, Washington, USA. Am. J. Bot. 86(3):307-325.

Boyd, D.R. 1959. Stratigraphy of the Difunta Group in an area north of Saltillo, Coahuila, México. MS thesis. University of Texas, Austin.

Burckhardt, C. 1930. Etude Synthétique sur le Mésozoique mexicain: Second partie. Mem. Soc. Paléont. Suisse, 50:125-280.

Calvillo-Canadell, L. 2000. Determinación taxonómica de estructuras reproductivas y vegetativas de plantas fósiles de Tepexi de Rodríguez, Puebla. Ms Tesis. Univ. Nac. Autón. Mex.

Cevallos-Ferriz, S.R.S., and Ricalde-Moreno, O.S. 1995. Palmers fósiles del Norte de México. An. Inst. Biol., Univ. Nac. Autón. Mex., Ser. Bot. 66 (1):37-103.

Cevallos-Ferriz, S.R.S., Estrada-Ruiz, E., and Pérez-Hernández, B.R. 2008. Phytolaccaceae infructescence from Cerro del Pueblo Formation, Upper Cretaceous (late Campanian), Coahuila, Mexico. Am. J. Bot., 95(1):1-77-83.

Cevallos-Ferriz, S.R.S., and Huerta-Vergara, A.R. 2015. Contexto geológico y fitogeografía de las plantas del Cretáceo de México, Boletín Geológico y Minero 126(1):21-36.

Cifuentes-Ruiz. P., Vršanský, P., Vega. F.J., Cevallos-Ferriz, S.R.S., González-Soriano, E., and Delgado de Jesús, C.R. 2006. Terrestrial arthropods from the Cerro del Pueblo 
Formation (Campanian, Late Cretaceous), Difunta Group, northeastern Mexico. Geol. Carpath. 57:347-54.

Coney, P. J. 1983. Un modelo tectónico de México y sus relaciones con América del Norte, América del Sur, y el Caribe. Rev. Inst. Mex. Pet. 15:6-15.

Crane, P.R, Pedersen, K.R., Friis, E.M., and Drinnan, A.N. 1993. Early Cretaceous (Early to Middle Albian) platanoid inflorescens associated with Sapindopsis leaves from the Potomac Group of Eastern North America. Syst. Bot. 18:328-44.

Dallwitz, M.J. 2010. Overview of the DELTA System, (in line). 27 December 2010, (09-102012). Available in: http://delta-intkey.com

Dickinson, W.R., and Lawton, T.F. 2001. Carboniferous to Cretaceous assembly and fragmentation of Mexico. Geol. Soc. Am. Bull. 113 (9): 1142-1160.

Duncan, T., and Meacham, C. 1987. MEKA Manual. University Herbarium, University of California, Berkeley, California.

Eberth, D.A., Delgado-de Jesús, C.R., Lerbekmo, J.F., Brinkman, D.B., Rodríguez-de la Rosa, R.A., and Sampson, S.D. 2004. Cerro del Pueblo Fm. (Difunta Group, Upper Cretaceous), Parras Basin, Southern Coahuila, Mexico: reference sections, age, and correlation. Rev. Mex. Cienc. Geol. 21(3):335- 352.

Endress, P.K., 1993. Hamamelidaceae. In The Families and Genera of Vascular Plants, vol. 2. Edited by K. Kubitzki, Springer, New York, USA, pp. 322-331.

Estrada-Ruíz, E. 2004. Frutos permineralizados del Cretácico Superior del Estado de Coahuila, México. M.Sc. Thesis, Univ. Nac. Autón. Mex. 
Estrada-Ruiz E., and Cevallos-Ferriz, S.R.S. 2007. Infructescences from the Cerro del Pueblo Formation (Late Campanian), Coahuila, and El Cien Formation (OligoceneMiocene), Baja California Sur, Mexico. Int. J. Plant Sci. (Chicago, IL, U. S.) 168(4): 507-519.

Estrada-Ruiz, E., Martínez-Cabrera, H.I. and Cevallos-Ferriz, S.R.S. 2007. Fossil wood from the late Campanian-early Maastrichtian Olmos Formation, Coahuila, Mexico. Rev. Palaeobot. Palynol. 145:123-133.

Estrada-Ruiz, E., Upchurch, G.R., and Cevallos-Ferriz, S.R.S. 2008. Flora and climate of the Olmos Formation (Upper Campanian-Lower Maastrichtian), Coahuila, Mexico: A preliminary report. Trans. - Gulf Coast Assoc. Geol. Soc. 58:273-283.

Estrada-Ruiz, E., Calvillo-Canadell, L., and Cevallos-Ferriz, S.R.S. 2009. Upper Cretaceous aquatic plants from Northern Mexico. Aquat. Bot. 90:282-288.

Estrada-Ruiz, E., Upchurch Jr., G.R., Wolfe, J.A., and Cevallos-Ferriz, S.R.S. 2011. Comparative morphology of fossil and extant leaves of Nelumbonaceae, including a new genus from the Late Cretaceous of Western North America. Syst. Bot. 36 (2): 337-351.

Floyd, S.K., Lerner, V.T., and Friedman, W.E. 1999. A Developmental and evolutionary analysis of embryology in Platanus (Platanaceae), a Basal Eudicot. Am. J. Bot. 86(11): 1523-37.

Friis, E.M., Crane, P.R., and Pedersen, K.R. 1988. Reproductive structures of Cretaceous Platanaceae. Biol. Skr. - K. Dan. Vidensk. Selsk. 31:1-55. 
Friis, E.M., Crane, P.R., and Pedersen, K.R. 2011. Early Flowers and Angiosperm Evolution. Cambridge University Press, Cambridge.

Fuentes, M. 1994. The effect of unripe fruits on ripe fruit removal by birds in Pistacia terebinthus: flag or handicap? Oecol. 101(1):55-58.

Gates, T., Sampson, S., Eberth, D., Hernández-Rivera, R., Aguillón, M., and Delgado-de Jesús, C. 2005. A new genus and species of lambeosaurine hadrosaur (Dinosauria: Ornithopoda) from the Late Campanian Cerro del Pueblo Formation, Coahuila, Mexico. J. Vertebr. Paleontol. 25(3): 62A.

Graham, S.W., and Barrett, S.C.H. 1995. Phylogenetic systematics of Pontederiales: implications for breeding-system evolution. In Monocotyledons: Systematics and Evolution. Vol. 2.. Edited by P.J., Rudall, D.F., Cribb, A.B., Cutler, and C.J., Humphries. Royal Botanic Gardens, Kew. pp. 415-441.

Hernández-Castillo, G., and Cevallos-Ferriz, S.R.S. 1999. Reproductive and vegetative organs with affinities to Haloragaceae from the Upper Cretaceous Huepac chert locality of Sonora, México. Am. J. Bot. 86(12):1717-34.

Hernández, R. 1992. New Dinosaur finds in the Cerro del Pueblo Formation (Upper Cretaceous, Campanian) from Coahuila state, Mexico. J. Vertebr. Paleontol. 12 (suppl): $32 \mathrm{~A}$.

Hernández, R., and Kirkland, J.I. 1993. The rediscovery of a rich upper-most Campanian dinosaur locality in the Cerro del Pueblo Fm., Coahuila, Mexico. J. Vertebr. Paleontol. 13 (suppl): $41 \mathrm{~A}$. 
Hernández, R., Aguillón-Martínez, C., Delgado-de Jesús, C.R., and Gómez, N.R. 1995. The Mexican dinosaur National Monument. J. Vertebr. Paleontol. 15 (suppl): 34 A.

Kirkland, J., Hernández-Rivera, R., Aguillón-Martínez, C., Delgado-de Jesús, C., GómezNunez, R., and Vallejo, I. 2000. The late Cretaceous Difunta Group of the Parras Basin, Coahuila, Mexico, and its Vertebrate Fauna. Guide Book of the Field Trips, Society of Vertebrate Paleontology, Mexico, pp 131-172.

Kirkland, J., and Aguillón-Martínez, C. 2002. Scizorbia: a unique sawfish paradigm from Difunta Group, Coahuila, Mexico. Rev. Mex. Cienc. Geol. 19:16-24.

Kirkland, J., Hernández-Rivera, R., Gates, T., Paul, G.S., Nesbit, S., Serrano-Brañas, C.I., and García-de la Garza, J.P. 2006. Large hadrosaurine dinosaur from the latest Campanian of Coahuila, México. In Late Cretaceous vertebrates from the Western Interior. Edited by S.G., Lucas, and R.M. Sullivan. NMMNH\&S Bulletin 35. New Mexico pp. 299-316.

Macbride, E.F., Weidei, A.E, Wolleben, J.A., and Laudon, R.C. 1974. Stratigraphy and structure of the Parras and La Popa basins, northeaster Mexico. Geol. Soc. Am. Bull. 85(10):1603-1622.

Magallón-Puebla, S., and Cevallos-Ferriz, S.R.S. 1994. Latest occurrence of the extinct genus Cedrelospermum (Ulmaceae) in North America: Cedrelospermum manchesteri from Mexico. Rev. Palaeobot. Palynol. 81:115-128.

Magallón-Puebla, S. 1997. Affinity within Hydrangeaceae of a structurally Late Cretaceous flowers (Conacian-Santonian of Georgia). Am. J. Bot. (supplement): pp 215. 
Moreno, P.N. 1984. Glosario Botánico Ilustrado. Instituto Nacional de Investigaciones sobre Recursos Bióticos. Jalapa, Mexico pp 300.

Manchester, S.R. 1986. Vegetative and reproductive morphology of an extinct plane tree (Platanaceae) from the Eocene of Western North America. Bot. Gaz. (Chicago) 147(2):200-226.

Maslova, N.P., and Kodrul, T.M. 2003. New platanaceous inflorescens Archaranthus gen. nov. from the Maastrichtian-Paleocene of the Amur Region. Paleontol. J. 37:89-98.

Maslova, N.P., and Herman, A.B. 2006. Infructescence of Friisicarpus nom. Nov. (Platanaceae) and associated foliage of the platanoid type from the Cenomanian of Western Siberia. Paleontol. J. 40:109-113.

Maslova, N.P. 2009. New genus Sarbaicarpa gen. nov. (Hamamelidales) from the Cenomanian-Turonian of Western Kazakhstan. Paleontol. J. 10:1281-1297.

McBride, E.F., Weidei, A.E., Wolleben, J.A., Laudon, R.C. 1974. Stratigraphy and Structure of the Parras and La Popa basins, Northeastern Mexico. Geol. Soc. Amer. Boll. 85 (10): 1603-1622.

McNamara, K.J., and Scott, J.K. 1983. A new species of Banksia (Proteaceae) from the Eocene Merlin Leigh Sandstone of the Kennedy Range, Western Australia. Altering 7:185-193.

Mai, D.H. 1995. Tertiäre Vegetationsgeschichte Europas. Gustav Fischer Verlag. Jena, Stuttgart, New York.

Prasanna, V., Prabha, T.N., and Tharanathan, R.N. 2007. Fruit ripening phenomena-an overview. Crit. Rev. Food Sci. Nutr. 47(1):1-19. 
Pedersen, K.R., Friis, E.M., Crane, P.R., and Drinnan, A.N. 1994. Reproductive structures of an extinct platanoid from the Early Cretaceous (latest Albanian) of Eastern North America. Rev. Palaeobot. Palynol. 80:291-303.

Pigg, K.B., and DeVore, M.L. 2005. Paleoactaea gen. nov. (Ranunculaceae) from the Paleogene of North Dakota and the London Clay. Am. J. Bot. 92: 1650- 1659.

Pigg, K.B., Eckert-Bond, S.M., and Jun Wen. 2004. Anatomically preserved Liquidambar (Altingiaceae) from the middle Miocene of Yakima Canyon, Washington state, USA, and its biogeographic implications. Am. J. Bot. 91(3): 499-509.

Prieto-Márquez, A., and Serrano-Braña, C.I. 2012. Latirhinus uitstlani, a 'broad-nosed' saurolophine hadrosaurid (Dinosauria, Ornithopoda) from the late Campanian (Cretaceous) of Northern Mexico. Historical Biology: An International Journal of Paleobiology 1072954:37-41.

Rámirez, J.L., and Cevallos-Ferriz, S.R.S. 2000. Consideraciones sobre las angiospermas (plantas con flor) fósiles en México. Geos 20(4):433-444.

Rodríguez-de la Rosa, R.A., and Cevallos-Ferriz, S.R.S. 1994. Upper Cretaceous Zingiberalean fruits whit in situ seeds from Southeastern Coahuila, Mexico. Int. J. Plant Sci. 155:786-805.

Rodríguez-de la Rosa, R.A., Cevallos-Ferriz, S.R.S., and Silva-Pineda A., 1998. Paleobiological implications of Campanian coprolites. Paleogeogr. Paleoclimatol. Palaeoecol. 142:231-254. 
Rodríguez-de la Rosa, R.A., and Cevallos-Ferriz, S.R.S. 1998. Vertebrates of the El Pelillal locality (Campanian, Cerro del Pueblo Formation), southeastern Coahuila, México. J. Vertebr. Paleontol. 18:751-764.

Silva-Pineda, A. 1984. Frutos del Cretácico Superior del estado de Coahuila, México. Memoria del III Congreso Latinoamericano de Paleontología, pp 432-37.

Sims, H.J., Herendeen, P.S., and Crane, P.R. 1998. A new genus of fossil Fagaceae from the Santonian (Late Cretaceous) of central Georgia, USA. Int. J. Plant Sci. (Chicago, IL, U.S.A.) 159:391-404.

Swamy, B.G.L. and Parameswaran, N. 2008. The helobial endosperm. Biological Reviews $38(1): 1-50$.

Takahashi M., Friis, E.M., Herendeen, P.S., and Crane P.R. 2008. Fossil flowers of Fagales from the Kamikitaba Locality (Early Coniacian; Late Cretaceous) of Northeastern Japan. Int. J. Plant Sci. (Chicago, IL, U.S.A.)169: 899-907.

Taylor, A., and Hopper, D. 1988. The Banksia Atlas (Australian Flora and Fauna Series Number ). Australian Government Publishing Service. Canberra.

Telefax, M.V., and Denk, T. 2012. Sporoderm ultrastructure of Platanus quedlinburgensis Pacltová emend. Tschan, Denk von Balthazar from the Late Cretaceous of Germany. Paleobotánica 52:177-91.

Vaughan, T.W. 1900. Reconnaissance in the Rio Grande coalfields of Texas. Bull. - Geol. Surv. USA. 164:100. 
Villanueva-Amadoz, U., Calvillo-Canadell, L., and Cevallos-Ferriz, S.R.S. 2014. Síntesis de los trabajos paleobotánicos del Cretácico en México. Bol.Soc. Geol. Mex. 66(1):197121.

Watson, L., and Dallwitz, M.J. 1992. The Families of Flowering Plants: Descriptions Illustrations, Identification, and Information Retrieval. http://biodiversity.uno.edu/delta/

Weber, R. 1972. La vegetation maestrichtiana de la Formación Olmos de Coahuila, México. Bol. Soc. Geol. Mex. 33:5-19.

Weber, R. 1978. Some aspects of the Upper Cretaceous angiosperm flora of Coahuila, Mexico. CFS, Cour. Forschungsinst. Senckenberg 30:38-46.

Weishampel, D.B. 1990. Dinosaurian distribution. In The Dinosauria. Edited by Weishampel, D.B., Dodson, P., and H. Osmólska. California University Press, Berkeley. 63-139.

Woolleben, J.A.1997. Paleontology of the Difunta Group (Upper Cretaceous-Tertiary) in Northern Mexico. J. Paleontol. 51:373-398.

Yarmolenko, A.V. 1935. Upper Cretaceous flora of the Northwestern Kara-Tau. Trudy Sredneaziatskogo Gosu- darstvennogo Universiteta, seriya VIII-B. Botanika 28:3-36 (in Russian).

Zhou, Z., Crepet, W.L., and Nixon, K.C. 2001. The earliest fossil evidence of the Hamamelidaceae: Late Cretaceous (Turonian) inflorescences and fruits of Altingioideae. Am. J. Bot. 88:753-766. 


\section{Table 1}

\begin{tabular}{|c|c|c|c|c|}
\hline $\begin{array}{c}\text { Taxon } \\
\text { (order/family) }\end{array}$ & Age & Locality & State & Reference \\
\hline Arales & $\begin{array}{l}\text { Late Upper } \\
\text { Cretaceous }\end{array}$ & Cerro del Pueblo Formation & Coahuila & $\begin{array}{l}\text { Estrada-Ruiz \& Cevallos-Ferriz, } \\
2007\end{array}$ \\
\hline Lythraceae & Upper Cretaceous & Cerro del Pueblo Formation & Coahuila & Estrada-Ruiz et al., 2009 \\
\hline Musaceace & Upper Cretaceous & Cerro del Pueblo Formation & Coahuila & $\begin{array}{l}\text { Rodríguez-de la Rosa \& } \\
\text { Cevallos Ferriz, } 1994\end{array}$ \\
\hline Nelumbonaceae & Upper Cretaceous & Cerro del Pueblo Formation & Coahuila & Estrada-Ruiz et al., 2011 \\
\hline Phytolaccaceae & Upper Cretaceous & Cerro del Pueblo Formation & Coahuila & Cevallos-Ferriz et al., 2008 \\
\hline Proteaceae & Upper Cretaceous & Cerro del Pueblo Formation & Coahuila & Estrada-Ruiz et al., 2011 \\
\hline Ranunculaceae & Upper Cretaceous & Cerro del Pueblo Formation & Coahuila & $\begin{array}{c}\text { Rodríguez-de la Rosa et } \\
\text { al.,1998 }\end{array}$ \\
\hline Haloragaceae & Cretaceous & Huepac & Sonora & $\begin{array}{c}\text { Hernández-Castillo \& Cevallos- } \\
\text { Ferriz, } 1999\end{array}$ \\
\hline Strelitziaceae & Upper Cretaceous & Cerro del Pueblo Formation & Coahuila & $\begin{array}{l}\text { Rodríguez-de la Rosa \& } \\
\text { Cevallos Ferriz, } 1994\end{array}$ \\
\hline Zingiberales & Upper Cretaceous & Cerro del Pueblo Formation & Coahuila & $\begin{array}{l}\text { Rodríguez-de la Rosa \& } \\
\text { Cevallos-Ferriz, } 1994\end{array}$ \\
\hline *Leguminaceae & $\begin{array}{l}\text { Oligocene-Miocene- } \\
\text { Eocene }\end{array}$ & $\begin{array}{l}\text { Coayuca Formation / La } \\
\text { Carroza Formation }\end{array}$ & Puebla & Calvillo-Canadell, 2000 \\
\hline Rhamnaceae & Oligocene-Miocene & Coayuca Formation & Puebla & Calvillo-Canadell, 2000 \\
\hline Ulmaceae & Oligocene & Píe de Vaca & Puebla & $\begin{array}{c}\text { Magallón-Puebla \& Cevallos- } \\
\text { Ferriz, } 1994 \text { a }\end{array}$ \\
\hline
\end{tabular}

Described fossil fruits in the Mexican territory. Those with an asterisk $\left(^{*}\right)$ are represented by more than three reports. 
Table

\begin{tabular}{|c|c|c|c|c|c|c|c|c|c|c|c|c|c|c|}
\hline FAMILY & $\begin{array}{c}\text { Infructescence } \\
\text { type }\end{array}$ & Fruit type & $\begin{array}{c}\text { External fruit } \\
\text { envelope }\end{array}$ & $\begin{array}{c}\text { Number } \\
\text { of } \\
\text { Carpels }\end{array}$ & $\begin{array}{c}\text { Ovary } \\
\text { possition }\end{array}$ & $\begin{array}{c}\text { Gynoecium } \\
\text { type }\end{array}$ & $\begin{array}{c}\text { Number } \\
\text { of } \\
\text { Styles }\end{array}$ & $\begin{array}{c}\text { Number } \\
\text { of } \\
\text { locules }\end{array}$ & $\begin{array}{c}\text { Placentation } \\
\text { type }\end{array}$ & Ovule type & $\begin{array}{l}\text { Seeds } \\
\text { per } \\
\text { locule }\end{array}$ & $\begin{array}{l}\text { Endosperm } \\
\text { development }\end{array}$ & $\begin{array}{c}\text { Forma } \\
\text { del } \\
\text { embrión }\end{array}$ & $\begin{array}{l}\text { Seed } \\
\text { chanber }\end{array}$ \\
\hline Fossil & Spike, & $\begin{array}{l}\text { Nut, } \\
\text { Nutlet }\end{array}$ & Bracts & $1-4$ & Superior & Syncarpic & 1 & $1-4$ & Axile & Anatropous & 1 & Helobial & Straight & Yes \\
\hline Altingiaceae & $\begin{array}{l}\text { Sphaerical } \\
\text { Capitulum }\end{array}$ & Capsule & ----- & 2 & Inferior & Syncarpic & 2 & 2 & Axile & Anatropous & $20-50$ & Nuclear & Straight & - ----- \\
\hline Fagaceae & Capitulum & $\begin{array}{l}\text { Nut, } \\
\text { acorn }\end{array}$ & $\begin{array}{l}\text { Bracts } \\
\text { (cupule) }\end{array}$ & $3-6$ & Inferior & Syncarpic & & $2-3$ & $\begin{array}{l}\text { Axilar } \\
\text { Apical } \\
\text { marginal }\end{array}$ & & $1-2$ & ------- & Straight & -------- \\
\hline Platanaceae & Head & Achene & $\begin{array}{l}\text { Acrescent } \\
\text { trichomes }\end{array}$ & $5-8$ & Superior & Apocarpic & 1 & $5-8$ & $\begin{array}{l}\text { Apical } \\
\text { Marginal }\end{array}$ & Othotropous & $1-2$ & $\begin{array}{l}\text { Celular } \\
\text { *Helobial }\end{array}$ & Straight & ${ }^{*}$ Yes \\
\hline Proteaceae & $\begin{array}{l}\text { Spike } \\
\text { Racime }\end{array}$ & $\begin{array}{l}\text { Nut, } \\
\text { Nutlet, } \\
\text { Achene, } \\
\text { Drupe }\end{array}$ & $\begin{array}{c}4 \text { conate } \\
\text { sepals/bracts }\end{array}$ & 1 & Superior & Syncarpic & 1 & 1 & $\begin{array}{c}\text { Apical } \\
\text { Marginal }\end{array}$ & $\begin{array}{l}\text { Othotropous } \\
\text { Anatropous }\end{array}$ & $1-2$ & Nuclear & Straight & Yes \\
\hline
\end{tabular}


Morpho-anatomical characteristics of the fruits of 4 families compared with the fossil material. In red shared characteristics. With an asterisk $\left({ }^{*}\right)$ those characteristics present in a taxon. From: http://delta-intkey.com/angio/www/. 


\section{Figure captions}

Fig. 1. Location of the fossiliferous area in the State of Coahuila. (Figure produce by authors)

Fig. 2. Macroscopic view of Infructescence. Scales $=1 \mathrm{~cm}$, except where noted. A) Lateral view, IGMPB 10632. Scale $=2 \mathrm{~cm} \mathrm{~B}$ ) Cross section with individual fruits (arrow) IGMPB 10572. C). Longitudinal section through the infructescence peduncle with attached fruits (arrow) IGMPB 10573. D-E) Cross section of a fruits with different number of carpels (uni, bi and tetra carpellated fruits), IGMPB 10580. White lines drawn on the photos indicate the boundaries of fruits.

Fig. 3. Fruits, bracts and vascular bundles. Scales $=1 \mathrm{~cm}$, except where noted. A) Longitudinal section of a style (arrow). LPBC 1-8. Scale $20 \mu \mathrm{m}$. B) SEM view of capitated stigma. C). Longitudinal section of a stalked fruit (arrow). White lines show outline of one individual fruit. IGMPB 10584. D) Cross section of the peduncle with several vascular bundles (arrow), each measuring 125- $200 \mu \mathrm{m}$, in diameter. LPBC 10584. E). Radial section of the mesophyll in the proximal part of a bract, composed of isodiametric cells (arrow). LPBC1-7. Scale $80 \mu \mathrm{m}$. F) Radial section in the distal region of a bract, composed of parenchyma cells with intercellular spaces (arrow). LPBC1-7. Scale $80 \mu \mathrm{m}$.

Fig. 4. Cellular composition of the fruits. Scale $=20 \mu \mathrm{m}$, except where noted. A) Fruit with pericarp composed of three cell layers (arrows). LPBC1-9. Scale $5 \mu \mathrm{m}$. B). Tangential section showing macrosclereids (arrow) of exocarp. LPBC1-13. C) Radial section of style with exocarp composed of macrosclereids (arrow). LPBC1-13. Scale 
$100 \mu \mathrm{m}$. D) Tangential section showing mesocarp (arrow) and endocarp (arrow), composed of cells of pitted rectangular or isodiametric brachysclereids and undifferentiated layer (arrow). LPBC1-13. E) Radial section of style with sclereids in the mesocarp and endocarp (arrow). LPBC1-13. Scale $100 \mu \mathrm{m}$. F). Tangential section of the ovary axis with sclereids of the meso and endocarp close to the area of the placenta (arrow). C4-2. G). Radial section of the pedicel composed of macrosclerids (arrow). LPBC1-13.

Fig. 5. Cellular composition of seed and embryo. Scale $100 \mu \mathrm{m}$, except where noted. A) Radial section of fusiform seeds in a fruit. LPBC2-2. Scale $5 \mu \mathrm{m}$. B) Tangential section showing seeds attached to the placenta (arrow). IGM1040-7. Scale $20 \mu \mathrm{m}$. C) Tangential section showing seed coat composed of a single layer of crushed cells (arrow) and an undifferentiated layer (arrow). IGM1040-7. D) Tangential section of few endosperm cells. IGM1040-7. E) Tangential section showing nuclear endosperm. IGM1040-7. F) Tangential section of seed with helobial endosperm; cellular toward the periphery of the seed (arrow), nuclear endosperm near the placenta (arrow). Scale IGM1040-9. Scale $10 \mu \mathrm{m}$. G) Radial section of seed with hollow chamber surrounded by the two types of endosperm. LPBC2-2. Scale 20 $\mu \mathrm{m} . \mathrm{H})$ Radial section of a seed with embryo. IMG10404-6. Scale $5 \mu \mathrm{m}$.

Fig. 6. Reconstruction of a bicarpelar fruit before embryo development. A) bract that covers the fruit composed of parenchyma with intercellular spaces, B) Style covered by brachysclereids, C) Capitated stigma, D) Pedicel with brachysclereids, E) Exocarp, F) Mesocarp, G) Endocarp composed of brachysclereids, H) Locule, I) 
Seeds, J) seed coat composed of rectangular cells, K) Cellular endosperm, L)

Nuclear endosperm, M) Placenta covered by brachysclereids, N) Septum, Ñ)

Seminal chamber surrounded by cellular endosperm, O) seminal camera with nuclear endosperm.

Fig. 7. Reconstruction of a mature bicarpelar fruit. Compare with Fig. 6.

Fig. 8. Reconstruction of a tetracrpelar fruit transverse section. For details of cell types see Fig. 6.

Fig. 9. Reconstruction of a bicrpelar fruit transverse section. For details of cell types see

Fig. 6.

Fig. 10. Proposed reconstruction of the inflorescence that matured into the fossil infructescence based on observations of the immature fruits of the infructescences. 


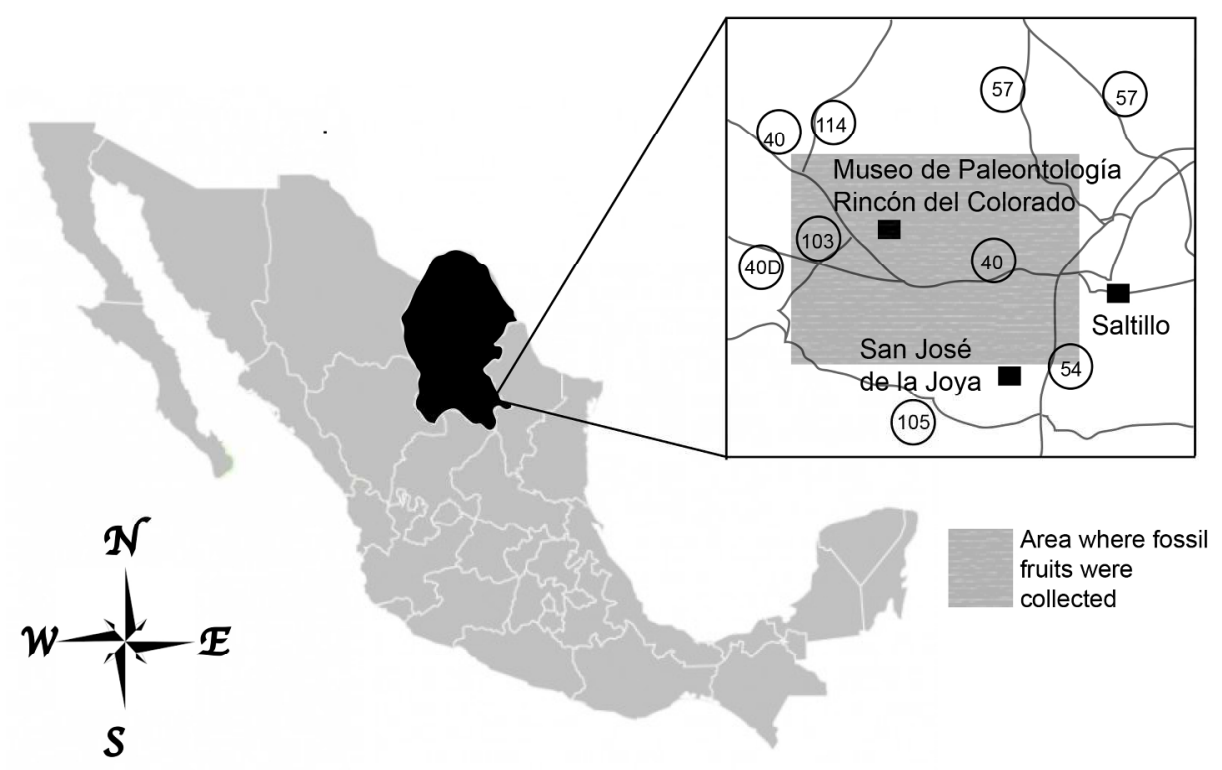

$205 \times 122 \mathrm{~mm}(300 \times 300$ DPI $)$ 


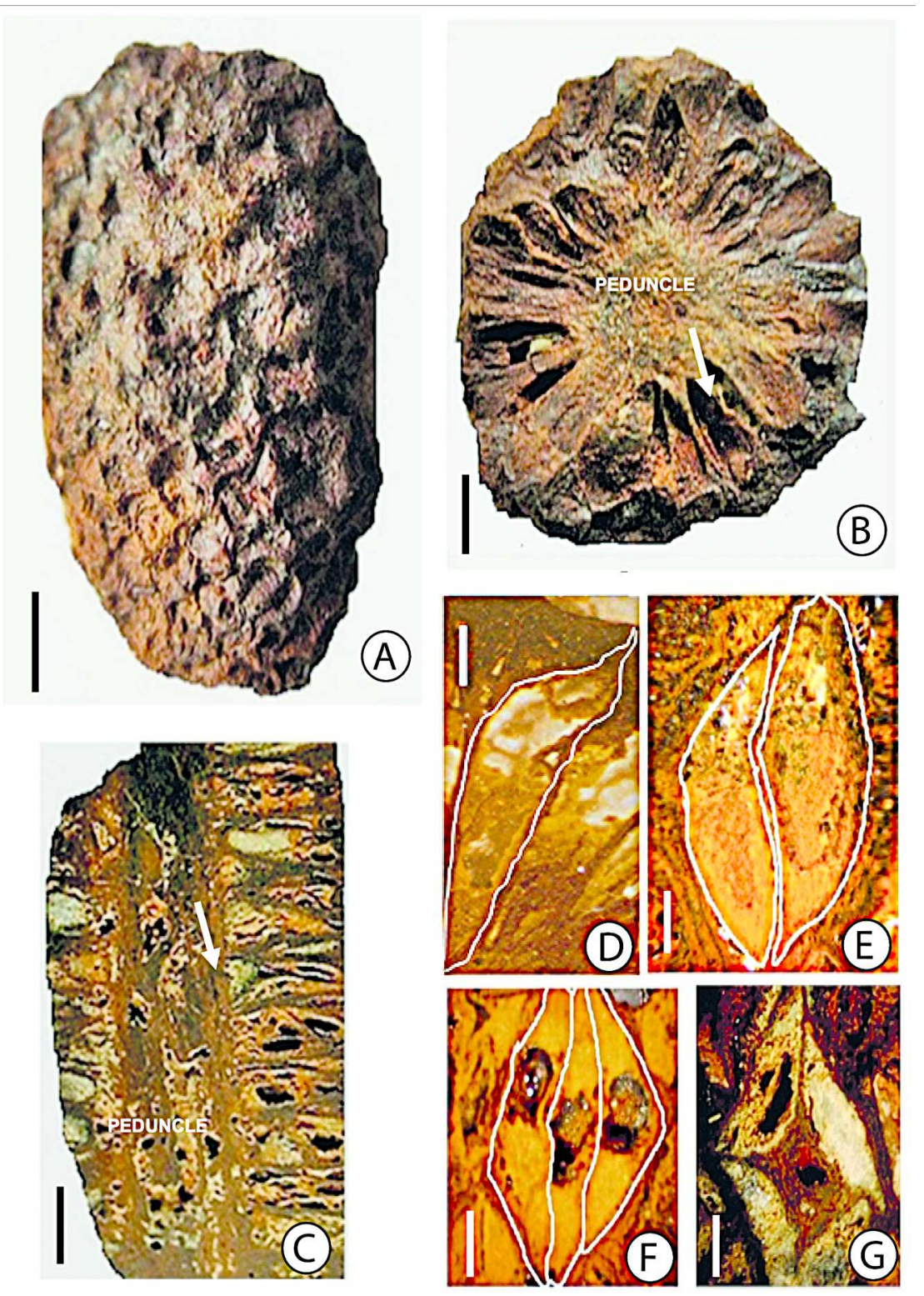

$143 \times 201 \mathrm{~mm}(300 \times 300$ DPI $)$ 

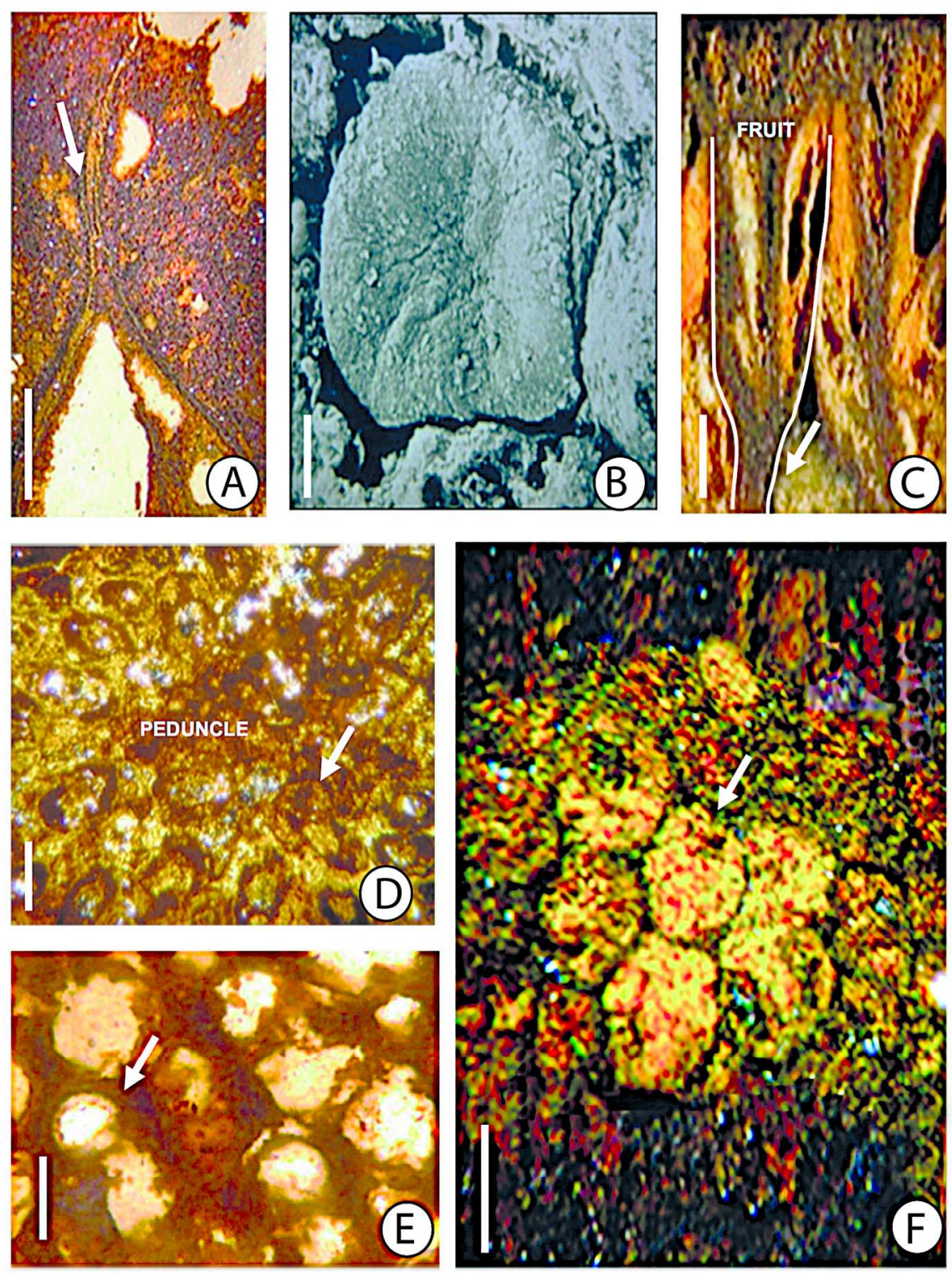

$140 \times 187 \mathrm{~mm}(300 \times 300 \mathrm{DPI})$ 

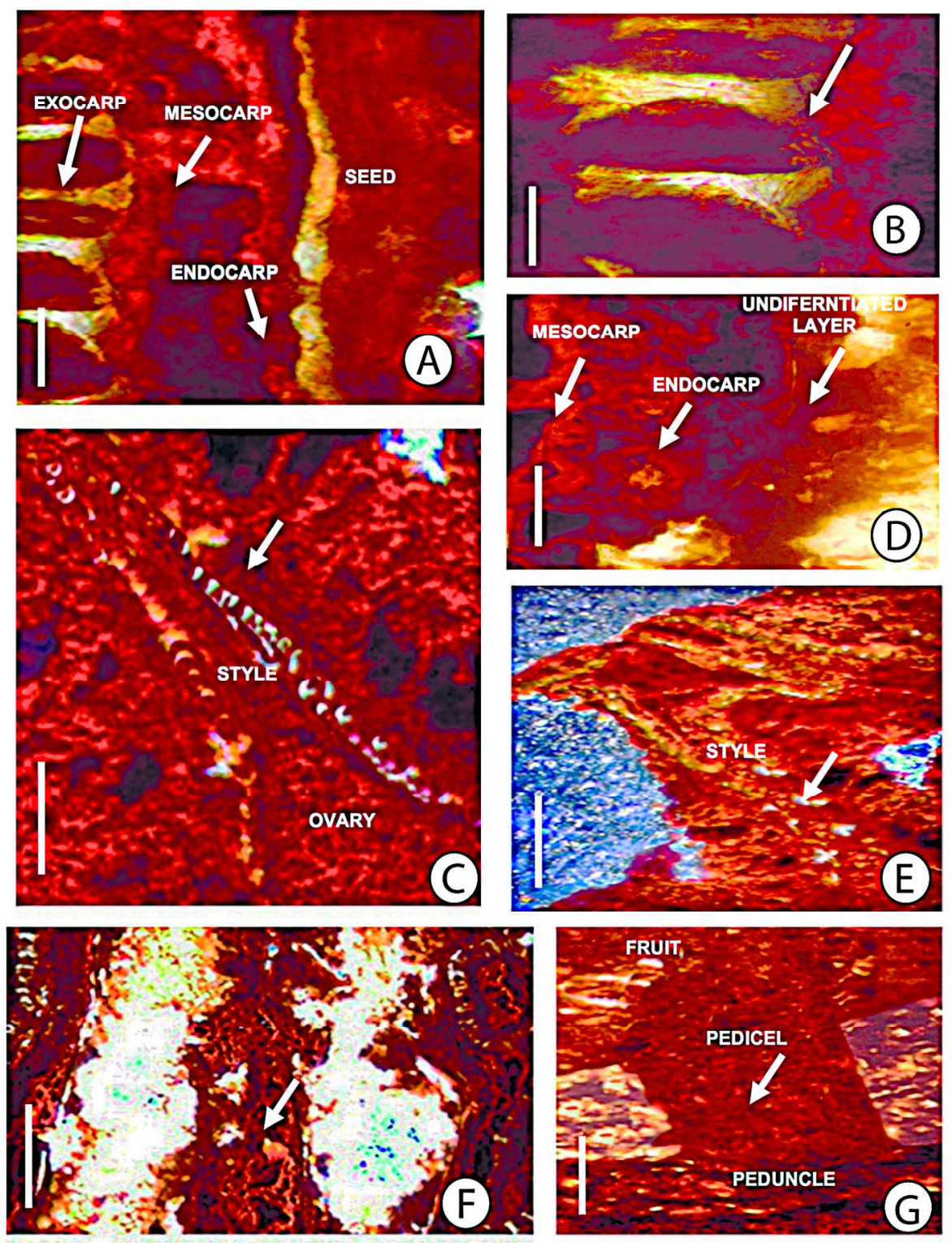

$147 \times 190 \mathrm{~mm}(300 \times 300$ DPI $)$ 

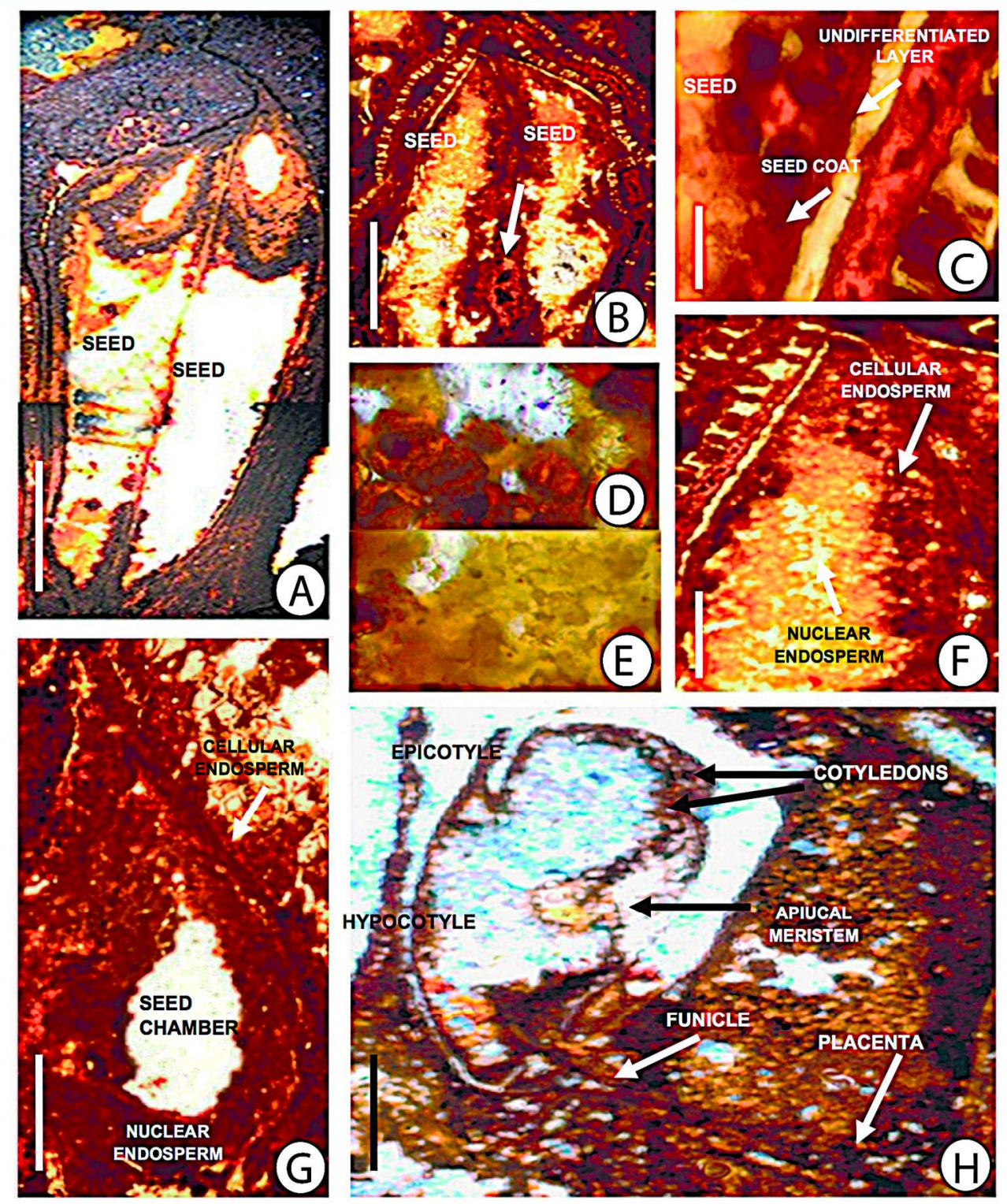

$148 \times 176 \mathrm{~mm}(300 \times 300$ DPI $)$ 


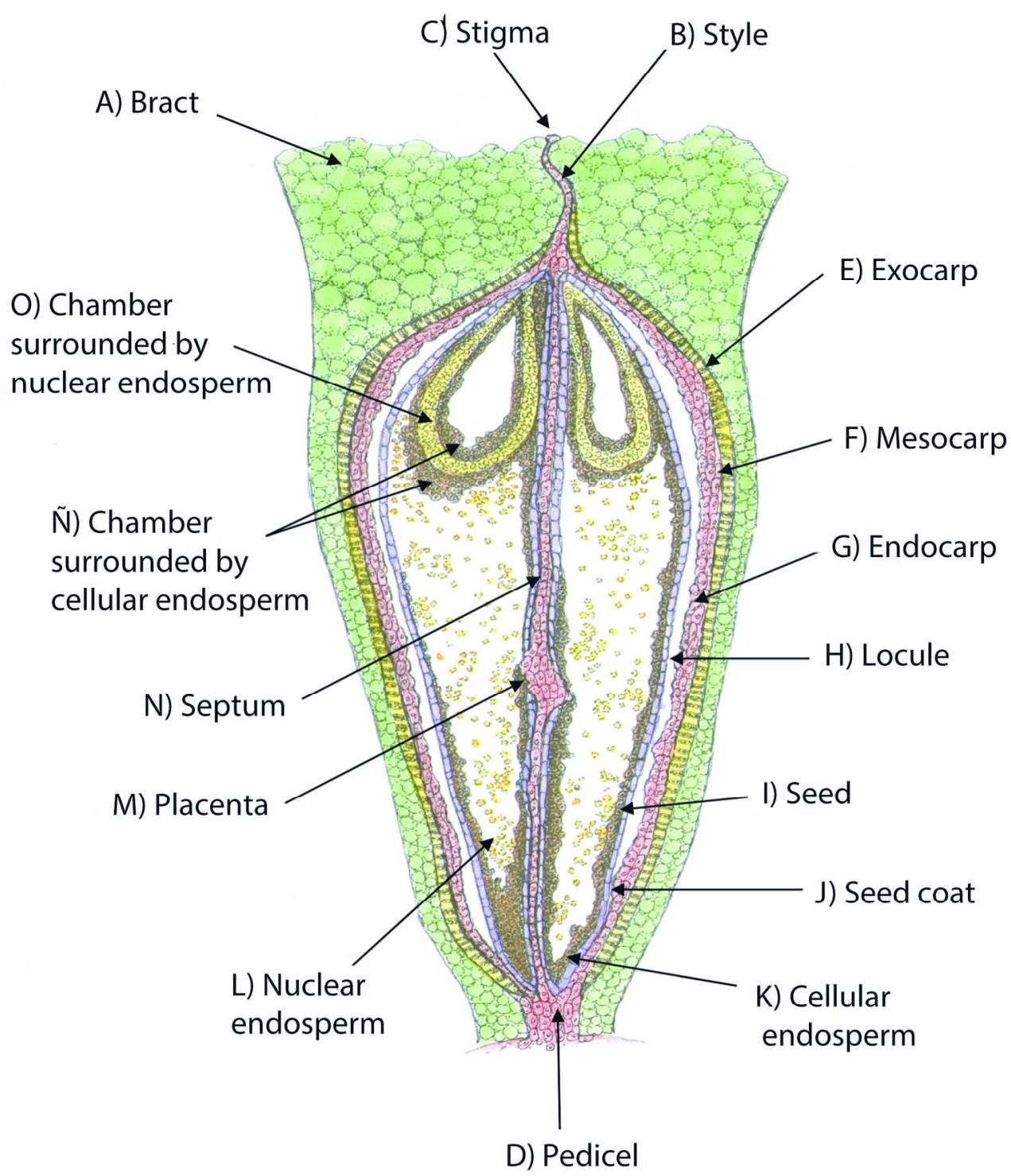

$158 \times 189 \mathrm{~mm}(300 \times 300 \mathrm{DPI})$ 


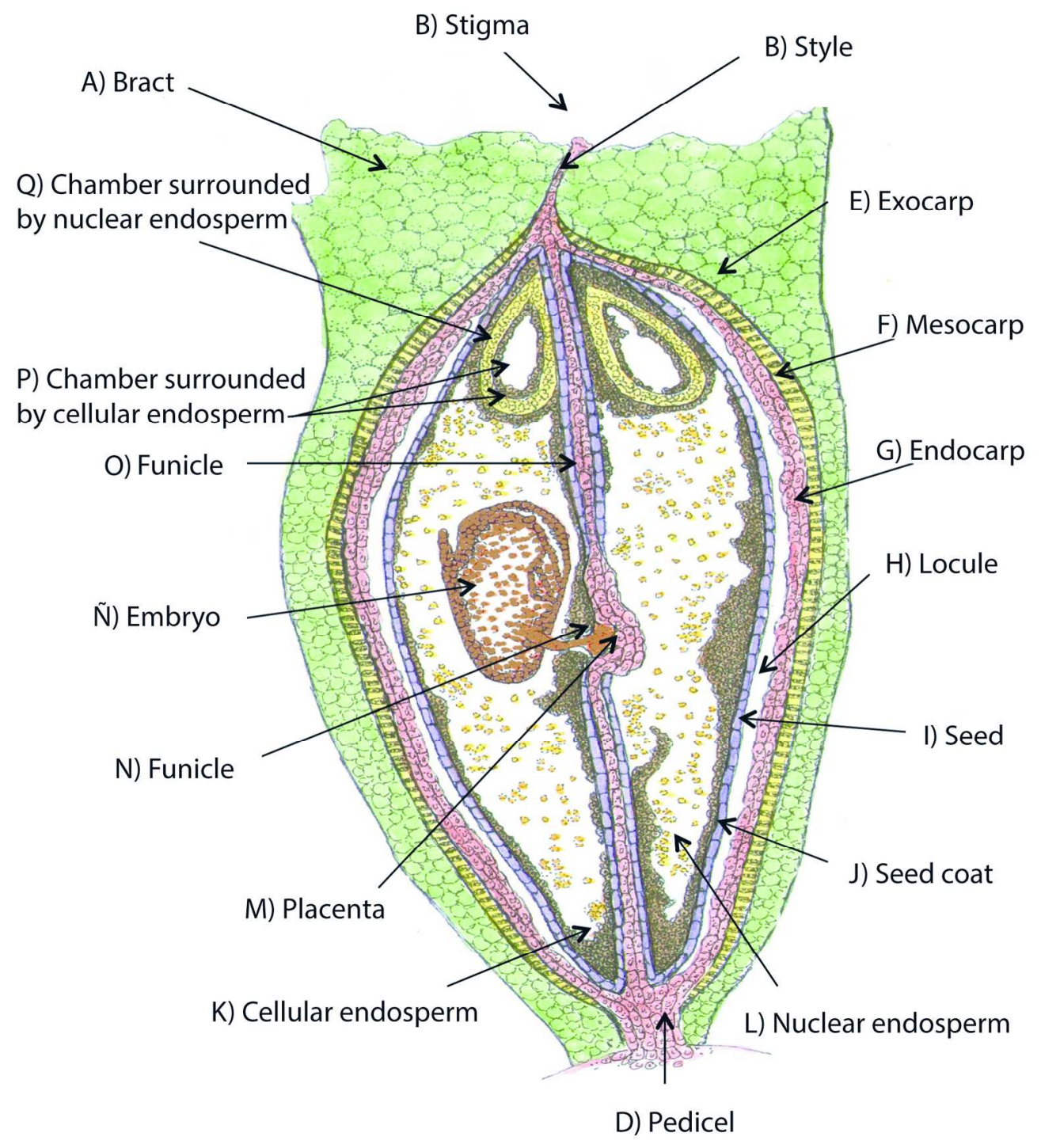

$175 \times 198 \mathrm{~mm}(300 \times 300$ DPI $)$ 


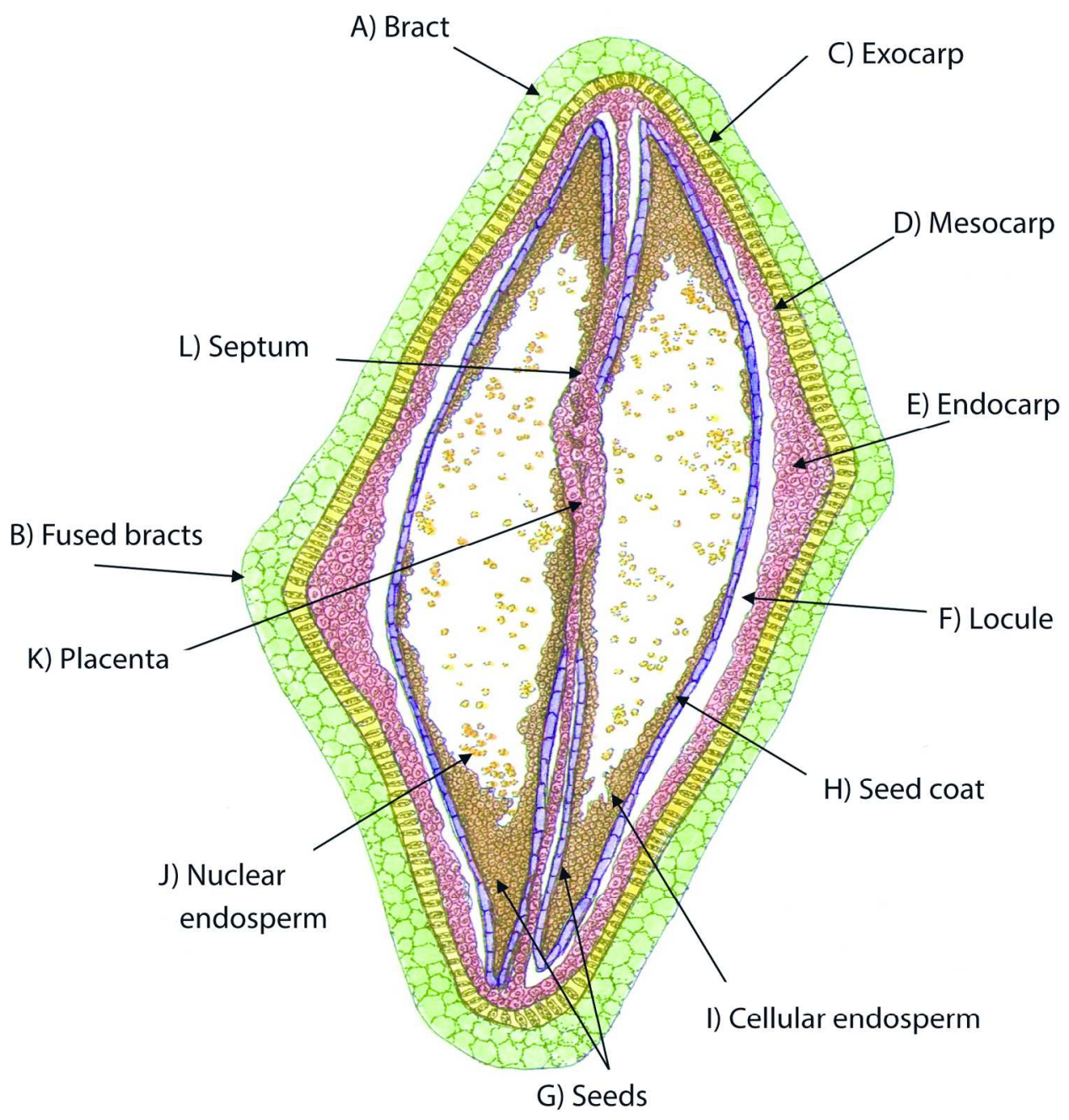

$175 \times 186 \mathrm{~mm}(300 \times 300 \mathrm{DPI})$ 


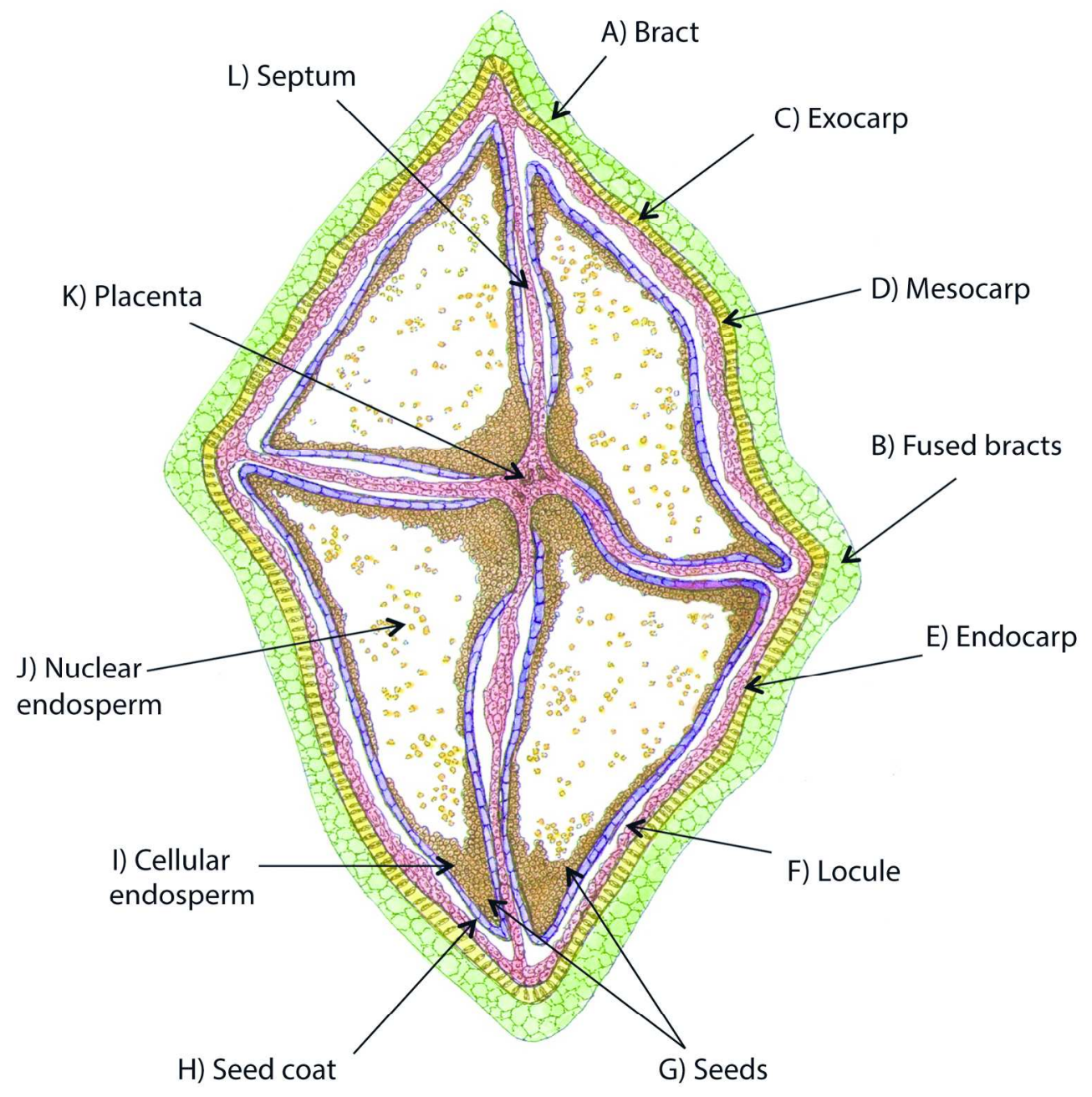

$176 \times 182 \mathrm{~mm}(300 \times 300 \mathrm{DPI})$ 


\section{A) Inflorescence}

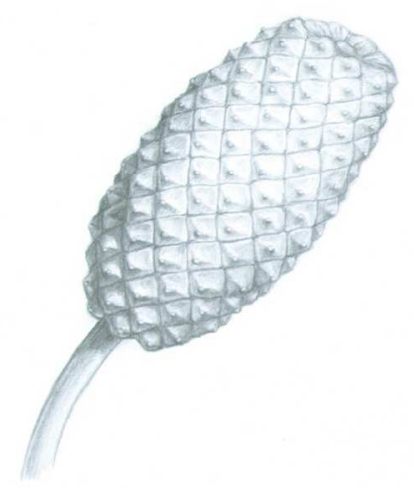

C) Floral diagram
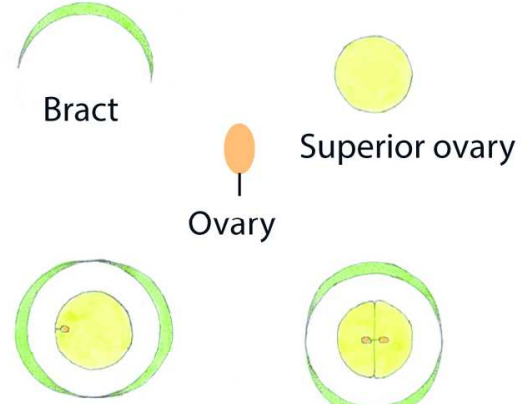

Unicarpelar

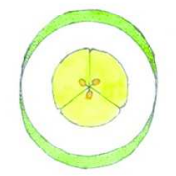

Tricarpelar

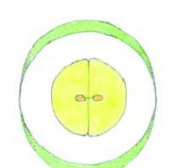

Bicarpelar

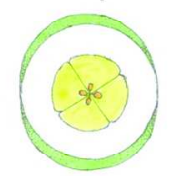

Tetracarpelar
B) Flower

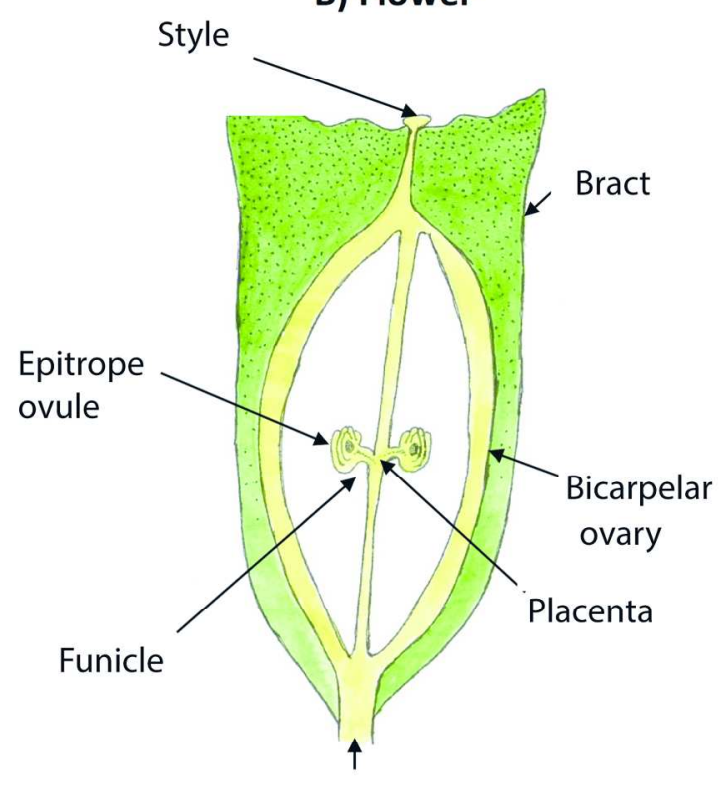

Pedicel

\section{D) Floral formula}

q + G(1-4)

$181 \times 202 \mathrm{~mm}(300 \times 300$ DPI $)$ 